\title{
Functional development of the human gastrointestinal tract: Hormone- and growth factor-mediated regulatory mechanisms
}

\author{
Daniel Ménard PhD
}

\begin{abstract}
D Ménard. Functional development of the human gastrointestinal tract: Hormone- and growth factor-mediated regulatory mechanisms. Can J Gastroenterol 2004;18(1):39-44.
\end{abstract}

The present review focuses on the control of gastrointestinal (GI) tract development. The first section addresses the differences in general mechanisms of GI development in humans versus rodents, highlighting that morphogenesis of specific digestive organs and the differentiation of digestive epithelia occur not only at different stages of ontogeny but also at different rates. The second section provides an overview of studies from the author's laboratory at the Université de Sherbrooke pertaining to the development of the human fetal small intestine and colon. While both segments share similar morphological and functional characteristics, they are nevertheless modulated by distinct regulatory mechanisms. Using the organ culture approach, the author and colleagues were able to establish that hormones and growth factors, such as glucocorticoids, epidermal growth factor, insulin and keratinocyte growth factor, not only exert differential effects within these two segments, they can also trigger opposite responses in comparison with animal models. In the third section, emphasis is placed on the functional development of human fetal stomach and its various epithelial cell types; in particular, the glandular chief cells responsible for the synthesis and secretion of gastric enzymes such as pepsinogen-5 and gastric lipase. Bearing in mind that limitations of available cell models have, until now, greatly impeded the comprehension of molecular mechanisms regulating human gastric epithelial cell functions, the last section focuses on new human gastric epithelial cell models recently developed in the author's laboratory. These models comprise a novel primary culture system of human fetal gastric epithelium including, for the first time, functional chief cells, and human gastric epithelium cell lines cloned from the parental NCI-N87 strain. These new cells lines could serve important applications in the study of pathogenic action and epithelial regeneration.

Key Words: Epithelial restitution; Fetal development; Human gastric epithelial cell models; Human gastrointestinal tract

\section{Le développement fonctionnel du tractus gastro- intestinal humain : Les mécanismes de régula- tion d'origine hormonale ou en provenance de facteurs de croissance}

La présente analyse porte sur le contrôle du développement du tractus gastro-intestinal (GI). La première partie traite des différences entre les mécanismes généraux de développement GI chez les humains par rapport aux rats et souligne que la morphogenèse d'organes digestifs précis et que la différenciation de l'épithélium digestif se produisent non seulement à différentes phases de l'ontogenèse, mais également à des rythmes variés. La deuxième partie procure un aperçu d'études menées dans notre laboratoire de l'Université de Sherbrooke sur le développement de l'intestin grêle et du côlon fœetaux. Tandis que les deux segments partagent des caractéristiques morphologiques et fonctionnelles similaires, ils sont modulés par des mécanisme de régulation distincts. Au moyen de cultures d'organes, nous avons pu établir que des hormones et des facteurs de croissance comme les glucocorticoïdes, le facteur de croissance épidermique, l'insuline et le facteur de croissance de la kératinocyte ont des effets différentiels dans ces deux segments, mais peuvent aussi déclencher des réponses opposées par ceux de modèles animaux. La troisième partie est axée sur le développement fonctionnel de l'estomac fotal humain et sur ses divers types de cellules épithéliales, et surtout sur les cellules adélomorphes glandulaires responsables de la synthèse et de la sécrétion d'enzymes gastriques comme le pepsinogène- 5 et la lipase gastrique. Puisque jusqu'à maintenant, le nombre limité de modèles de cellules disponibles a gravement entravé la compréhension des mécanismes moléculaires régulant les fonctions des cellules épithéliales gastriques humaines, la dernière partie s'intéresse aux nouveaux modèles de cellules épithéliales gastriques humaines récemment développés dans notre laboratoire. Ces modèles comportent un nouveau système de culture primaire d'épithélium gastrique foetal humain, y compris, pour la première fois, des cellules adélomorphes fonctionnelles et des lignées de cellules épithéliales gastriques humaines clônées de la souche NCI-N87 parentérale. Ces nouvelles lignées cellulaires ont des applications importantes dans l'étude de l'action pathogène et de la régénération épithéliale.

\section{DIFFERENTIAL CONTROL OF GASTROINTESTINAL DEVELOPMENT IN HUMANS AND RODENTS}

The development of specific digestive organs in utero and/or after birth occurs at differing rates and involves both morphogenesis and cytodifferentiation. In rodents, the functional changes leading to mature or adult functions in the various digestive organs (salivary glands, stomach, pancreas, intestine) are characterized by a highly coordinated developmental pattern occurring at weaning time $(1,2)$. As opposed to rodents, functional development of the human gastrointestinal (GI) tract is much less coordinated chronologically and occurs

CIHR Group on Functional development and physiopathology of the digestive tract Department of Anatomy and Cell Biology, Faculty of Medicine, Université de Sherbrooke, Sherbrooke, Québec

Correspondence and reprints: Dr Daniel Ménard, Département d'anatomie et de biologie cellulaire, Faculté de médecine, Université de Sherbrooke,

Sherbrooke, Quebec J1H 5N4. Telephone 819-564-5271, fax 819-564-5320, e-mail Daniel.Menard@USherbrooke.ca

Received for publication May 14, 2003. Accepted October 30, 2003 


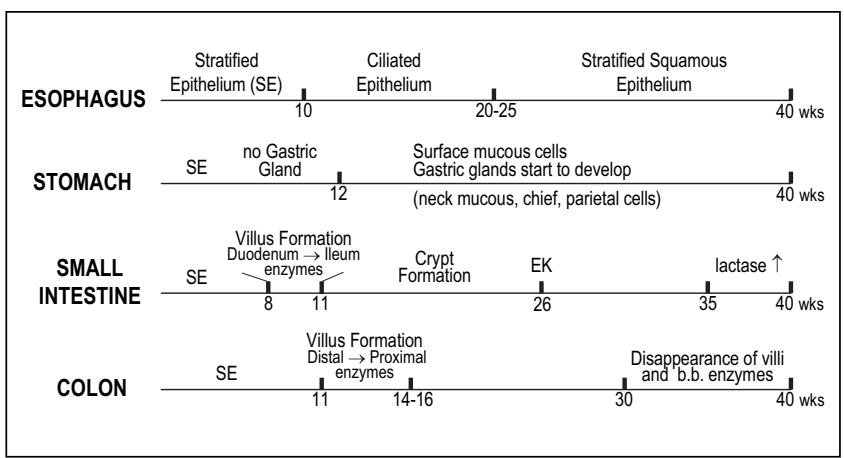

Figure 1) Representation of key events leading to the development of human gastrointestinal (GI) tract. The onset of morphological and functional changes occurs not only at different gestational periods but can also differ within a given segment of the GI tract. bb enzymes Intestinal brush border digestive enzymes; Distal $\rightarrow$ proximal Distal to proximal gradient of villus formation; Duodenum $\rightarrow$ ileum Establishment of a proximal-distal gradient of villus formation and brush border digestive enzymic activities; EK Appearance of enteropeptidase activity at 26 weeks of gestation; lactase $\uparrow$ Late gestational rise in lactase activity. Adapted from references 2 to 4

during the fetal period (Figure 1) $(3,4)$. Hence, by 15 to 20 weeks' gestation, morphological differentiation of the fetal gut essentially resembles that of the newborn. However, one must caution that digestive functions, on the other hand, develop not only at different rates throughout the various GI organs, but can also differ within a given organ (Figure 1). Henceforth, the regulatory mechanisms behind human GI tract development are seemingly different and undoubtedly more complex than in rodents.

The central issue has always been: what is, or more likely, what are the regulators or modulators of functional GI development? Since the pioneering work of Moog, glucocorticoid hormones have probably been the most studied modulator of intestinal development $(1,2)$. In rodents, an increase in circulating glucocorticoid concentrations (primarily corticosterone) at the onset of the third week of postnatal life, followed by changes in intestinal enzymic activities normally within the next $48 \mathrm{~h}$, have led to the first suggestion that glucocorticoids could be an important, if not the foremost, regulator of functional development occurring at weaning. For example, glucocorticoid administration to suckling animals has a broad effect on all digestive functions attributed to intestinal epithelial cells (disaccharidases, glucoamylase, alkaline phosphatase, peptidases), as well as to those attributed to gastric zymogenic chief cells (pepsin) and salivary glandular cells (amylase). While glucocorticoids have certainly been targeted, from the outset, as having a primary role in the regulation of functional GI tract development, many other hormones (thyroxine, insulin) as well as growth factors (epidermal growth factor [EGF], insulin-like growth factors, transforming growth factors [TGF], hepatocyte growth factor, keratinocyte growth factor) through various secretory pathways, have been proposed over the years as modulators of functional development leading to what is now a very complex regulatory mechanism (Figure 2).

Further compounding the issue is that depending on the animal model selected, one specific factor can have either a
Involvement of Hormones and Growth Factors: Delivery Pathways

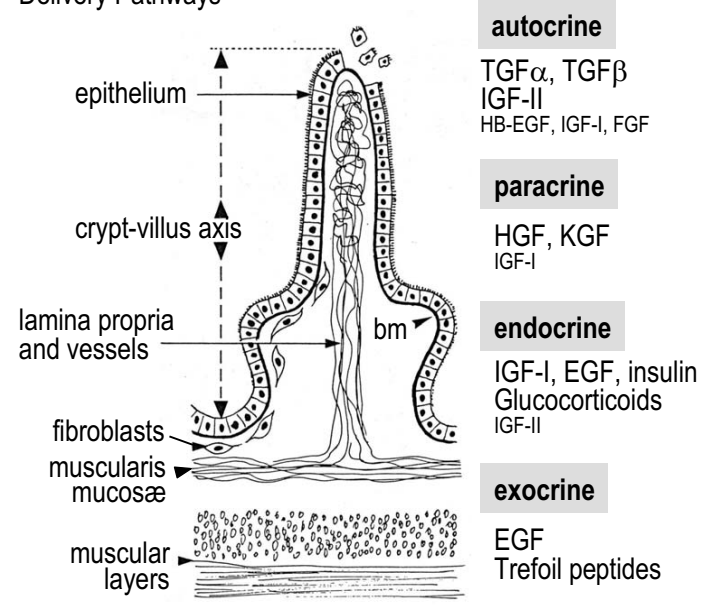

Figure 2) Schematic representation of the functional unit of the small intestinal mucosa (ie, crypt-villus axis) and involvement of possible growth factors and hormones delivered through various secretory pathways. bm basement membrane; EGF Epidermal growth factor; FGF Fibroblast growth factor; HB-EGF Heparin-binding EGF; HGF Hepatocyte growth factor; IGF-I,-II Insulin-like growth factors I and II; KGF Keratinocyte growth factor; TGF $\alpha, \beta$ : transforming growth factors- $\alpha$ and $-\beta$. Data are from references 1 to 4

potent, modest or even no effect on a given studied function. This phenomenon is well illustrated in the case of EGF. Whereas EGF was first reported to exert a drastic effect on the suckling mouse small intestine by stimulating cell proliferation, a precocious appearance of sucrase activity and a premature increase of several brush border enzymic activities (5), it has a relatively weak or no influence on these same functions in the rat small intestine (6). In light of these differences, as well as differing developmental profiles for rodents and humans, the question remains: is it prudent to extrapolate regulatory mechanisms characterized in rodents directly to the human GI tract?

\section{DEVELOPMENT OF HUMAN FETAL INTESTINE AND COLON}

To address this fundamental question, our research was oriented several years ago toward establishing an organ culture technique allowing for the morphological and functional maintenance of human fetal GI tract tissues in vitro $(7,8)$. The observation that human fetal serum hydrocortisone levels double during the last four weeks of gestation has often been interpreted as an indication of a possible specific modulatory influence of glucocorticoid hormones on human fetal intestine, especially in relationship with the perinatal increase in lactase activity (Figure 1). Using human fetal intestines aged 12 to 14 weeks cultured in serum-free medium, the effects of selected hydrocortisone (HC) levels, representative of consecutive gestational periods $(12.5 \mathrm{ng} / \mathrm{mL}, 15$ to 17 weeks; $25 \mathrm{ng} / \mathrm{mL}, 35$ weeks; $50 \mathrm{ng} / \mathrm{mL}, 37$ to 40 weeks), were assessed on both digestive functions and cell proliferation (9). The lowest dosage of $\mathrm{HC}$, corresponding to serum levels measured 
between 12 and 14 weeks of gestation, did not influence functional development. However, addition of $25 \mathrm{ng} / \mathrm{mL}$ and $50 \mathrm{ng} / \mathrm{mL}$ induced a significant rise in lactase activity without influencing other dissacharidase activities such as sucrase, trehalase and glucoamylase. Furthermore, $50 \mathrm{ng} / \mathrm{mL}$ HC treatment induced a significant rise in epithelial ${ }^{3} \mathrm{H}$-thymidine labelling index. In addition, the ability to culture human fetal colon in identical conditions (10) enabled us to evaluate and compare the involvement of glucocorticoid hormones in the modulation of colonic digestive enzymes and cell proliferation. In this instance, the addition of $\mathrm{HC}$ had effect neither on any of the brush border digestive enzymes nor on cell proliferation (11). The basic mechanism underlying the nonresponse of the fetal colon to $\mathrm{HC}$ remains to be determined. These data do strengthen, however, the notion that while glucocorticoid hormones are involved in the modulation of rodent and human GI functional development, their time of action as well as the physiological parameters specifically modulated by $\mathrm{HC}$ are quite dissimilar. Table 1 summarizes current knowledge of the specific effects of hormones and growth factors (known to be involved in rodent models) on human fetal small intestine and colon $(9,11-15)$. While it is obvious that human fetal small intestine and colon share the same morphological and functional characteristics, these two GI segments are under very different regulatory mechanisms. Furthermore, the same regulatory factors seem to trigger different and at times opposite effects in human fetal GI tract as opposed to in rodents, a situation well exemplified in Table 1 (9-16) when comparing EGF-induced stimulation of intestinal cell proliferation and premature appearance of sucrase activity in the mouse model (5) with the effects on the human fetal small intestine (12). Therefore, a great deal of caution is warranted in extrapolating data obtained from rodents directly to human fetal gut.

\section{FUNCTIONAL DEVELOPMENT OF HUMAN FETAL STOMACH}

The development of gastric glands (fundic-type or oxyntic) occurs very early during human fetal life (10 to 12 weeks of gestation), as opposed to rodent gastric glands which mature at a striking pace during the last few days of gestation (4). At eight to 10 weeks of gestation, human gastric epithelium is stratified and undifferentiated. By 11 to 12 weeks, the glandular pits are formed, along with the emergence of the first differentiated epithelial cell type, the parietal cell lineage. From 11 weeks onward, surface epithelial cells differentiate into columnar mucous cells while gastric glands continue to expand with the appearance of endocrine cells, neck mucous cells and chief cells. By 15 to 17 weeks of gestation, fetal gastric glands are basically representative of the adult gastric gland and exhibit all of the morphological compartments (foveolus, isthmus, neck and base) containing the various phenotypically-different cell lineages (Figure 3A). It should be noted that epithelial cells leaving the proliferative zone (isthmus) differentiate into mucin-5A-expressing mucous cells when migrating upwards and into mucin-6-expressing mucous, endocrine, parietal and chief cells when migrating downwards.

Much effort was spent in defining the functional compartmentalization of the human fetal gland as summarized in Figure 3B (17-23). As mentioned earlier, by 15 weeks of gestation, the fetal gland is representative of the adult gastric unit because all of the various functional compartments are fully determined; all differentiated epithelial cell types are in place;
TABLE 1 Effects of growth factors and hormones on the human
fetal gut

\begin{tabular}{|c|c|c|c|c|}
\hline & EGF & $\mathrm{HC}$ & Insulin & KGF \\
\hline \multicolumn{5}{|l|}{ Small intestine } \\
\hline proliferation & $\downarrow$ & $\uparrow$ & $\uparrow$ & $\uparrow$ \\
\hline sucrase & $\downarrow$ & $=$ & $=$ & $\uparrow$ \\
\hline lactase & $\uparrow$ & $\uparrow$ & $=$ & $=$ \\
\hline chylomicron & $\uparrow$ & $\downarrow$ & $\downarrow$ & ND \\
\hline VLDL & $\downarrow$ & $\downarrow$ & $=$ & ND \\
\hline $\mathrm{HDL}$ & $\downarrow$ & $\uparrow$ & $=$ & ND \\
\hline Apo A-1 & & $\uparrow$ & $=$ & ND \\
\hline Apo B-48 & & $\uparrow$ & $=$ & ND \\
\hline Apo B-100 & $\downarrow$ & $\downarrow$ & $=$ & ND \\
\hline \multicolumn{5}{|l|}{ Colon } \\
\hline proliferation & $\downarrow$ & $=$ & $\uparrow$ & $\uparrow$ \\
\hline sucrase & $=$ & $=$ & $=$ & $\downarrow$ \\
\hline lactase & $=$ & $=$ & $=$ & $=$ \\
\hline
\end{tabular}

Apo Apolipoprotein; EGF Epidermal growth factor; HC Hydrocortisone, HDL High density lipoprotein; KGF Keratinocyte growth factor; ND: not determined; VLDL Very low density lipoprotein; $\uparrow$ upregulation; $\downarrow$ downregulation; = no significant effect. Results from references 9-16

and all functional markers as well as known hormone and growth factor receptors are expressed. Moreover, the restricted distribution of extracellular matrix (ECM) components and integrin-type receptor is already established. This particular compartmentalization certainly raises numerous basic questions regarding the regulation of both development and maintenance of human gastric functions, including: are human gastric zymogens colocalized and coregulated? Which hormones and growth factors are involved in these processes? What role, if any, do laminins (LN) and their integrin receptors play in glandular formation and/or epithelial cell migration/differentiation?

In response to these queries, our first investigations were focused on the regulation of digestive functions of the gastric mucosa and especially on human gastric lipase (HGL). Accumulating evidence supports that digestion of dietary triglycerides by the stomach in normal physiological conditions is a prerequisite for efficient intestinal lipolysis. Furthermore, the importance of gastric lipolysis is further amplified within the context of perinatal physiology and in pathological conditions where secretion of gastric lipase could compensate for depressed pancreatic activities (17). Because HGL may assume a significant compensatory function in premature and newborn infants as well as in adult subjects, an understanding of the regulatory mechanisms controlling its synthesis and secretion is imperative. In addition, the human adult gastric mucosa exhibits a unique feature with regard to the cellular distribution of fundic-type pepsinogen $(\operatorname{Pg} 5)$ and HGL. Indeed, histochemical analyses have established that in the developing and adult human stomach, Pg5 and HGL are coexpressed in chief cells located at the base of glands. In contrast, in all known animal models, these two zymogens are either localized in different chief cell populations within the gastric gland or in separate gastric epithelial cell types (chief versus mucous cells) (17). This clearly illustrates the lack of an animal model to specifically address the regulation of gastric lipase in humans. 


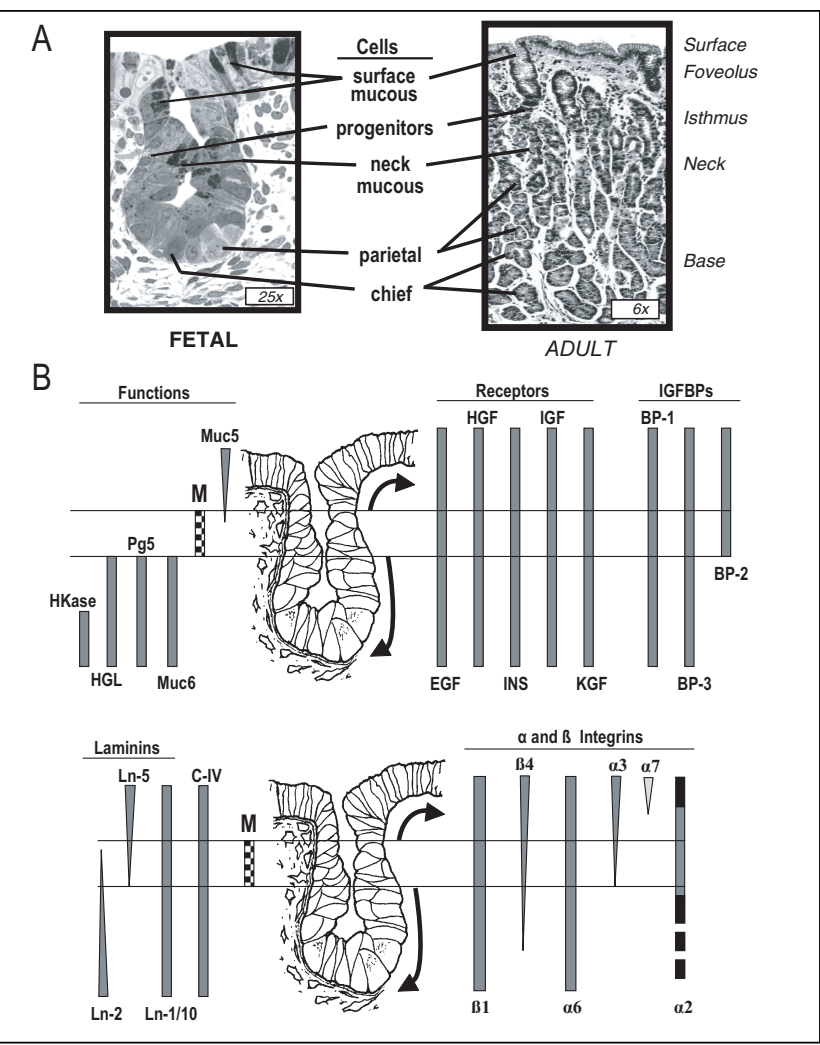

Figure 3) Morphological (A) and functional (B) compartmentalization of the gastric gland of the human gastric mucosa. A The fetal gastric gland (left) is basically representative of the adult gastric gland (right) and exhibits all of the morphological compartments (foveolus, isthmus, neck and base) containing the various epithelial lineages. B Various functional compartments of the gastric epithelium expressing functional markers (HKase Proton-potassium ATPase; HGL Human gastric lipase; Pg5 Pepsinogen 5; muc5,6 Mucins-5A,-6; M Mitogenic activity), hormone and growth factor receptors, insulin-like growth factor binding proteins (IGFBPs), extracellular matrix components (Ln Laminins, C-IV Collagen IV) and $\alpha, \beta$ integrin subunits. BP Binding protein; EGF; Epidermal growth factor; FGF Fibroblast growth factor; HGF Hepatocyte growth factor; IGF Insulin-like growth factor; INS Insulin; KGF Keratinocyte growth factor. Data are primarily from references 18 to 23

Between 12 and 20 weeks of fetal development, the correlation among human HGL activity, HGL protein and HGL mRNA signals strongly suggests that HGL expression is most likely regulated at the mRNA level. Moreover, the fact that adult-like regional distribution (fundus $\rightarrow$ antrum) of HGL activity is already in place at 15 to 16 weeks gestation, in contrast to that of Pg5 which is yet to be established, coupled with differing developmental profiles of HGL and Pg5 activities, strongly support the theory that both enzymes are under distinct regulatory mechanisms.

The serum-free organ culture model established earlier for the fetal gut also enabled us to identify and characterize possible modulators involved in the regulation of human fetal gastric mucosa (20). Several hormones and growth factors have been postulated as participants in the development and maintenance of gastric functions (21). EGF is involved in the maintenance of mucosal integrity because of its effects on protection, repair and healing processes and on the inhibition of gastric acid secretion. The fact that EGF receptors are
TABLE 2

Growth factors/hormones and human fetal stomach

\begin{tabular}{lccccc}
\hline & HC & EGF/TGF $\alpha$ & IGF-I & IGF-II & KGF $^{*}$ \\
\hline Proliferation & $=$ & $\uparrow$ & $\uparrow$ & $=(\uparrow)$ & $\uparrow$ \\
Mucus synthesis & $=$ & $\uparrow$ & $=$ & $=$ & $=$ \\
Pepsinogen-5 & $\uparrow$ & $=$ & $=$ & $=$ & $\uparrow$ \\
Gastric lipase & $=$ & $\downarrow$ & $\downarrow$ & $\downarrow$ & $\uparrow$ \\
& & \multicolumn{5}{c}{$\begin{array}{c}\text { Effects modulated } \\
\text { by IGFBPs }\end{array}$} \\
\end{tabular}

EGF/TGF $\alpha$ Epidermal growth factor/transforming growth factor- $\alpha$; $H C$ Hydrocortisone; IGF Insulin-like growth factor; IGFBPs IGF binding proteins; KGF Keratinocyte growth factor; $\uparrow$ Upregulation; $\downarrow$ Downregulation; = No significant effect. Results from references 21 to 23 and from unpublished data ( ${ }^{*}$ )

ubiquitously distributed along the foveolus-gland axis (Figure 3) in cell types exhibiting distinct physiological functions further prompted us to verify the possible implication of this growth factor in regulating Pg5 and HGL activities. Addition of EGF to cultured fetal gastric explants decreased tissular HGL activity but did not modulate Pg5 activity (21), further supporting the hypothesis that both digestive enzymes are under distinct regulation. Table 2 summarizes our current knowledge of factors involved in gastric functional development in terms of cell proliferation, mucus synthesis and gastric enzymic activities (Pg5, HGL) (21-23). Again, as observed for the small intestine (Table 1), notable specific and differential effects point to a very complex regulatory mechanism. Furthermore, a given factor may have a particular effect in the small intestine and the opposite effect in the stomach. Further studies will certainly be needed to fully comprehend the diversity and complexity of growth factor action.

In the case of HGL expression, our initial studies clearly indicate that the downregulation of HGL expression induced by EGF is the result of a down regulation at the HGL-mRNA level involving, in part, the activation of mitogen-activated protein kinase (MAPK) p42/p44 isoforms (23). Thus, organ culture technique in this instance again offers a unique opportunity not only to study the biological effects of a given factor but also to identify the molecular mechanisms behind these effects. On a cautious note, however, while organ culture models do allow for the study of global responses of gastric tissue to a given modulator, they do not allow to pinpoint specific pathways for a single cell type. Our understanding of the interactions between hormones and growth factors and interactions among epithelium, basal lamina and the mesenchyme is therefore of paramount importance, if we are to gain a better understanding of the molecular mechanisms involved in the maintenance of gastric functions in normal and pathological states.

\section{NEW HUMAN GASTRIC EPITHELIAL CELL MODELS}

To address these specific questions, a novel primary culture system of human fetal gastric epithelium (24) was developed in our laboratory, allowing for the establishment of coherent tight monolayers of pure epithelial cells composed of all epithelial cell types including, for the first time, gastric chief cells. Addition of EGF to these cell cultures induced a downregulation of HGL activity and HGL-mRNA without affecting Pg5, hence mimicking the response observed in organ culture. 


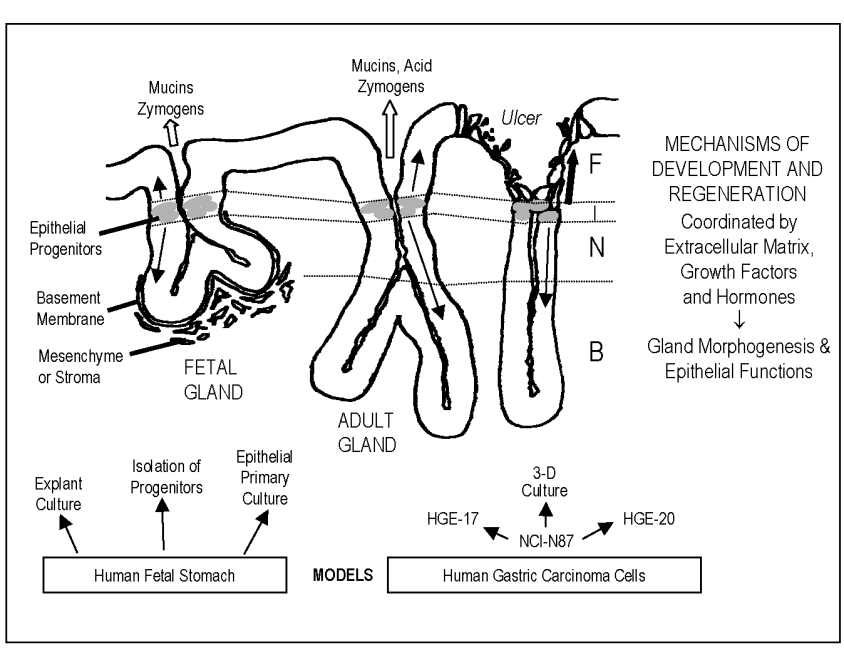

Figure 4) Schematic representation of normal fetal and adult gastric glands and their specific functional compartments (F Foveola; I Isthmus; N Neck; B base) and of diseased gland (ulcer). The mechanisms involved in the regulation of morphogenesis, maintenance and regeneration of the glandular structures are coordinated by extracellular matrix components, growth factors and hormones. The gastric tissue and cell models currently available for studying proliferation, migration, differentiation, cell polarity and secretion leading to the maintenance and repair of the human gastric mucosa are listed at the bottom of the figure. HGE Human gastric epithelium; NCI-N87 National Cancer Institute-N87. Data are primarily from references 27 to 28 and 30

Having established these functional epithelial cells in primary culture, we were now in a position to study the possible role of ECM components in the regulation of digestive functions. To assess the involvement of ECM proteins and transforming growth factor- $\beta 1$ (TGF- $\beta 1$ ) in this regulation, normal gastric epithelial cells were cultured on either type-I collagen, Matrigel (reconstituted basement membrane, BD BioSciences, Mississauga, Ontario) or laminins (LN-1 and LN-2) with or without TGF- $\beta 1$ (25). There was a clear correlation between cell polarity status and level of HGL expression. TGF- $\beta 1$ alone or individual matrix components stimulated cell spreading and caused a reduction in HGL activity and mRNA. By contrast, Matrigel preserved the morphological features of differentiated epithelial cells and maintained HGL expression. The combination of LNs with TGF- $\beta 1$ (two major constituents of Matrigel) exerted similar beneficial effects on epithelial cell polarity while eliciting a 10-fold increase in HGL levels that was otherwise blunted by the addition of a neutralizing antibody against the $\alpha 2$-integrin subunit or by the MAPK inhibitors PD98059 (p42/p44) or SB203580 (p38). These results bring to light for the first time that cell polarity and functionality of the human gastric glandular epithelium is positively influenced by the powerful synergism between a growth factor and basement membrane LNs through activation of $\alpha 2 \beta 1$ integrin and effectors of two MAPKs pathways. Thus, the use of primary cultures offers a unique tool for the study of the molecular mechanisms behind the regulation of human gastric epithelial cell functions. Unfortunately, the availability of fetal tissues will always remain a constant limitation in this type of approach.
Hence, the next step was to determine if we could find or establish a human gastric cell line with true epithelial characteristics. The potential usefulness of gastric cancer cell lines for elucidating the process of human gastric epithelial functional differentiation, and especially chief cell lineage, has never been addressed partly due to the lack of any known normal human gastric epithelial cell lines. Our first task was therefore to perform a detailed analysis of the functional differentiation status (junctional proteins, tyrosine kinase receptors, mucins, digestive enzymes, phenotype) of several known representative gastric cancer cell lines (26). Of all the cell lines studied, NCIN87 cells exhibited a unique differentiation status, forming coherent monolayers expressing E-cadherin protein in all cells and ZO-1 protein in a subpopulation of cells. Furthermore, these cells are able to synthesize PAS-reactive (mucous-type) glycoconjugates and express mucin- 6 glycoprotein, suggesting a mucopeptic phenotype. NCI-N87 cells are the only cells able to express zymogens in granule-like structures in one of their subpopulations and to efficiently secrete both HGL and Pg5, thus highlighting the potential usefulness of this gastric cell line as a model for elucidating the cellular and molecular mechanisms involved in the regulation of human gastric epithelial functions (27).

Using the limit dilution approach, we then generated new nontransfected clones isolated from the NCI-N87 strain, followed by functional characterization. Twenty-one clones exhibiting epithelial type junctions were isolated and renamed HGE (human gastric epithelium) cell lines. Among these clones, HGE-17 and HGE-20 displayed a homotypic phenotype and formed dense coherent monolayers (28) exhibiting surface microvilli, apical junctions and desmosomes at the ultrastructural level. For the first time, E-cadherin and ZO-1 proteins were persistently localized at the periphery of all gastric cells which generated transepithelial electrical resistance comparable to well-known cell lines such as MDCK, Caco-2 upon reaching confluency.

With the establishment of these human cell lines in tight monolayers, we were now in a position to specifically address human gastric epithelial regeneration. Several earlier studies carried out on epidermal and retinal cells suggest that the process of epithelial regeneration after wounding is highly coordinated according to the following pattern: death and desquamation of damaged cells at the wound site; alteration of epithelial phenotype at wound edges due to cytoplasmic spreading and partial dissociation of cell-to-cell junctions; induction of migratory structures with the formation of lamellipodia and stress fibres; and finally, increase in cell density by compensatory proliferation. The first three events correspond to the phase called restitution. What we know of GI epithelial restitution and the regulatory potential of hormones/growth factors has been obtained from the intestinal epithelial cell-6 (IEC-6) epithelial cell line isolated from the rat intestine. The general concept is that numerous growth factors and cytokines are able to stimulate intestinal epithelial restitution in vitro (EGF, TGF- $\alpha$, TGF- $\beta$, interleukin- $1 \beta$, interferon- $\gamma$ ) but their actions are all TGF- $\beta$-dependent (29) because the simultaneous addition of an antibody against TGF- $\beta 1$ abolishes their effects. In an attempt to see whether this concept could be applicable to gastric epithelium, the wounding assay developed for intestinal cells was applied to the HGE-17 cell line. Preliminary results indicate that EGF/TGF- $\alpha$ strongly stimulate cell migration (number of cells across the wound edge), as 
observed for intestinal cells, but that the EGF/TGF- $\alpha$-stimulated migration is independent of TGF- $\beta 1$. To delineate whether this different behaviour was specific to the gastric epithelial cells and not related to the cancerous origin of HGE cells, we validated this response using normal human gastric epithelial cells isolated from fetal stomach and maintained in primary culture. The data obtained to date are very similar to those obtained with HGE cells, strongly suggesting that HGE-17 cells respond to the same growth factors as in normal cells and the regulation mechanisms for the human gastric epithelium are different from those found in the small intestine. Obviously, the availability of the new HGE-17 and -20 cell lines will offer unique opportunities to fully characterize the cellular and molecular mechanisms involved in gastric epithelial regeneration.

\section{PERSPECTIVES}

As summarized in Figure $4(27,28,30)$, over the years we have been able to develop and characterize new techniques and appropriate human gastric tissue and cell models to specifically address basic questions relevant to the physiopathology of the gastric epithelium. Over and above certain inherent limitations, the integration of the body of data generated by all of these various models will ultimately lead to the emergence of new concepts and therapeutic approaches pertaining to the homeostasis of human gastric mucosa.

\section{REFERENCES}

1. Henning SJ. Postnatal development: Coordination of feeding, digestion and metabolism. Am J Physiol 1981;241:G199-214.

2. Ménard D, Calvert R. Fetal and postnatal development of the small and large intestine: Patterns and regulation. In: Morisset J, Solomon T, eds. Growth of the Gastrointestinal Tract: Gastrointestinal Hormones and Growth Factors. Boca Raton: CRC Press Inc, 1991:147-62.

3. Ménard D. Growth promoting factors and the development of the human gut. In: Lebenthal E, ed. Human Gastrointestinal Development. New York: Raven Press, 1989:123-50.

4. Montgomery RK, Mulberg AE, Grand RI. Development of the human gastrointestinal tract: Twenty years of progress. Gastroenterology 1999;116:702-31.

5. Malo C, Ménard D. Influence of epidermal growth factor on the development of suckling mouse intestinal mucosa. Gastroenterology 1982;83:28-35.

6. Pollack PA, Goda T, Colony PC, et al. Effects of enterally fed epidermal growth factor on the small and large intestine of the suckling rat. Regul Pept 1987;17:121-32.

7. Ménard D, Arsenault P. Explant culture of human fetal small intestine. Gastroenterology 1985;88:691-700.

8. Ménard D. Organ culture studies of human gastrointestinal development. In: Smith MW, Sepulveda FV, eds. Adaptation and Development of Gastrointestinal Function. Manchester: Manchester University Press, 1989:80-91.

9. Arsenault P, Ménard D. Influence of hydrocortisone on human fetal small intestine in organ culture. J Pediatr Gastroenterol Nutr 1985;4:893-901.
10. Ménard D, Arsenault P. Human fetal colon in organ culture. Anat Embryol 1987;176:441-8.

11. Ménard D, Corriveau L, Arsenault P. Differential effects of epidermal growth factor and hydrocortisone in human fetal colon. J Pediatr Gastroenterol Nutr 1990;10:13-20.

12. Ménard D, Arsenault P, Pothier P. Biological effects of epidermal growth factor in human fetal jejunum. Gastroenterology 1988;94:656-63.

13. Ménard D, Corriveau L, Beaulieu JF. Insulin modulates cellular proliferation in developing human small intestine and colon. Biol Neonate 1999;75:143-51.

14. Chailler P, Basque JR, Corriveau L, Ménard D. Functional characterization of the keratinocyte growth factor system in human gastrointestinal tract. Pediatr Res 2000;48:504-10.

15. Lévy É, Ménard D. Developmental aspects of lipid and lipoprotein synthesis and secretion in human gut. In: Bendayan M, ed. Structural and Functional Relationships of the Intestinal Wall. Microsc Res Tech 2000;49:363-73.

16. Ménard D. Development of human intestinal and gastric enzymes. Acta Paediatr Suppl 1994;405:1-6.

17. Ménard D, Monfils S, Tremblay E. Ontogeny of human gastric lipase and pepsin activities. Gastroenterology 1995;108:1650-6.

18. Chénard M, Basque JR, Chailler P, Beaulieu JF, Ménard D. Expression of integrin subunits correlates with differentiation of epithelial cell lineages in developing human gastric mucosa. Anat Embryol 2000;202:223-33.

19. Ménard D, Arsenault P. Cell proliferation in developing human stomach. Anat Embryol 1990;182:509-16.

20. Ménard D, Arsenault P, Monfils S. Maturation of human fetal stomach in organ culture. Gastroenterology 1993;104:492-501.

21. Tremblay É, Monfils S, Ménard D. Epidermal growth factor influences cell proliferation, glycoproteins and lipase activity in human fetal stomach. Gastroenterology 1997;112:1188-96.

22. Tremblay É, Chailler P, Ménard D. Coordinated control of fetal gastric epithelial functions by insulin-like growth factors and their binding proteins. Endocrinology 2001;142:1795-803.

23. Tremblay É, Basque JR, Rivard N, Ménard D. Epidermal growth factor and transforming growth factor- $\alpha$ downregulate human gastric lipase gene expression. Gastroenterology 1999;116:831-41.

24. Basque JR, Chailler P, Perreault N, Beaulieu JF, Ménard D. A new primary culture system representative of the human gastric epithelium. Exp Cell Res 1999;253:493-502.

25. Basque JR, Chailler P, Ménard D. Laminins and transforming growth factor-beta maintain cell polarity and functionality of human gastric epithelium. Am J Physiol (Cell Physiol) 2002;282:C873-84.

26. Basque JR, Chénard M, Chailler P, Ménard D. Human gastric cancer cell lines as models to study digestive functions. J Cell Biochem 2001;81:241-51.

27. Basque JR, Ménard D. Establishment of culture systems of human gastric epithelium for the study of pepsinogen and gastric lipase synthesis and secretion. In: Bendayan M, ed. Structural and Functional Relationships of the Intestinal Wall. Microsc Res Tech 2000;49:293-302.

28. Ménard D, Gaudreau MA, Chailler P. Human gastric epithelial (HGE) cell lines exhibiting epithelial barrier function and increased zymogen synthesis. Gastroenterology 2002;122:A245.

29. Dignass AU, Podolsky DK. Cytokine modulation of intestinal epithelial restitution: Central role of transforming growth factor beta. Gastroenterology 1993;105:1323-32.

30. Chailler P, Ménard D. Three-dimensional culture to study human gastric gland morphogenesis. Gastroenterology 2002;122:A245. 


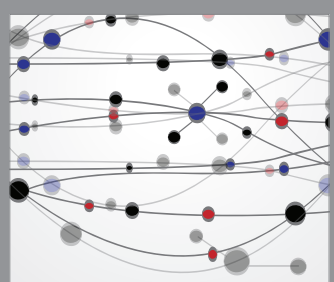

The Scientific World Journal
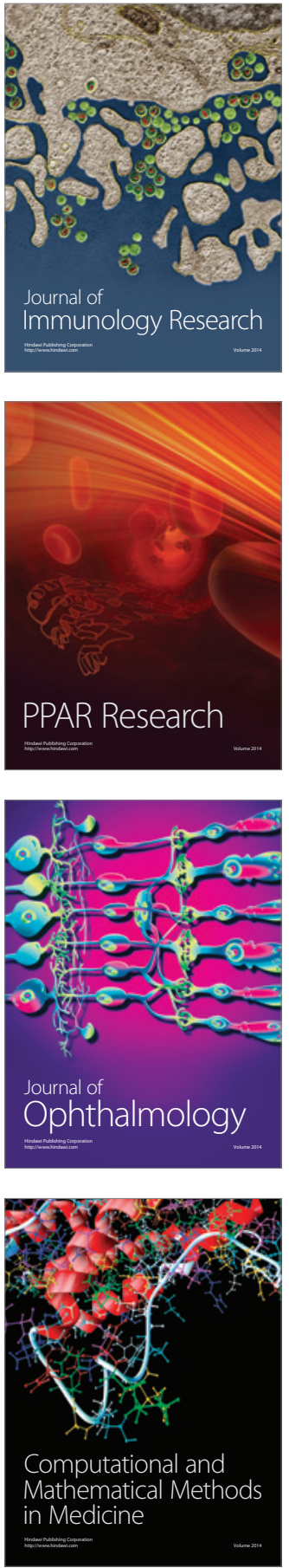

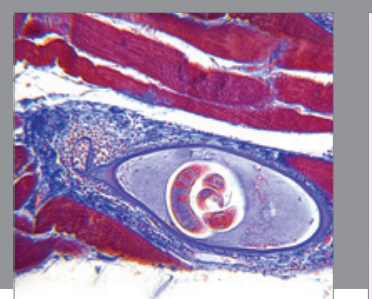

Gastroenterology Research and Practice

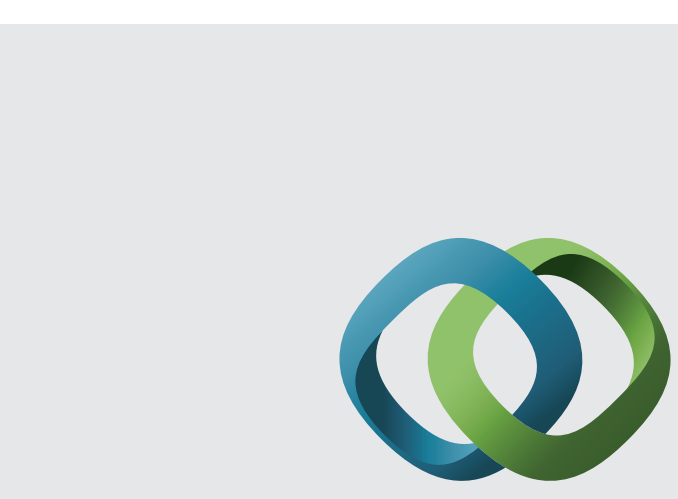

\section{Hindawi}

Submit your manuscripts at

http://www.hindawi.com
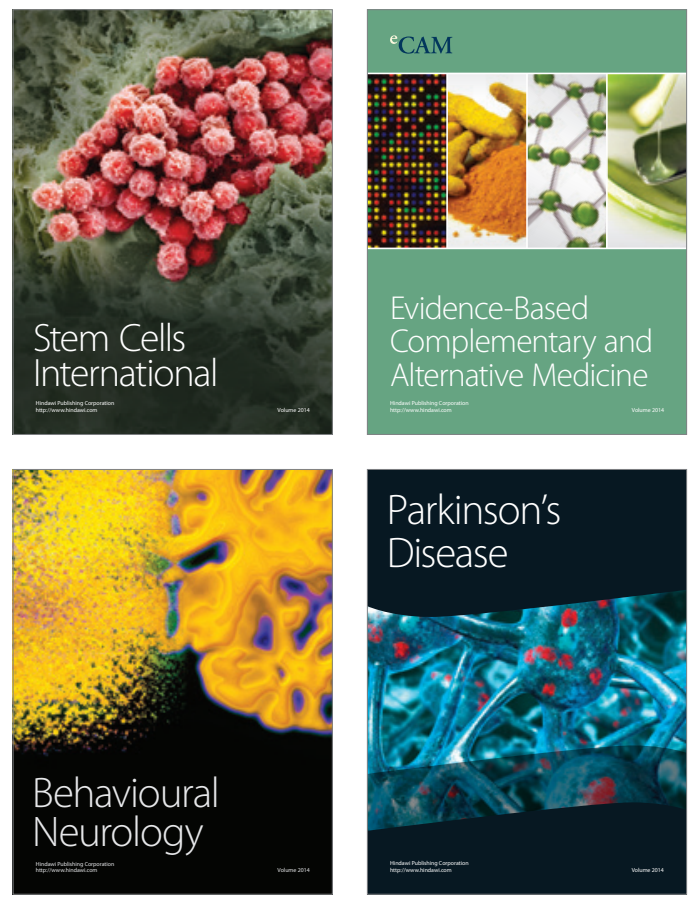
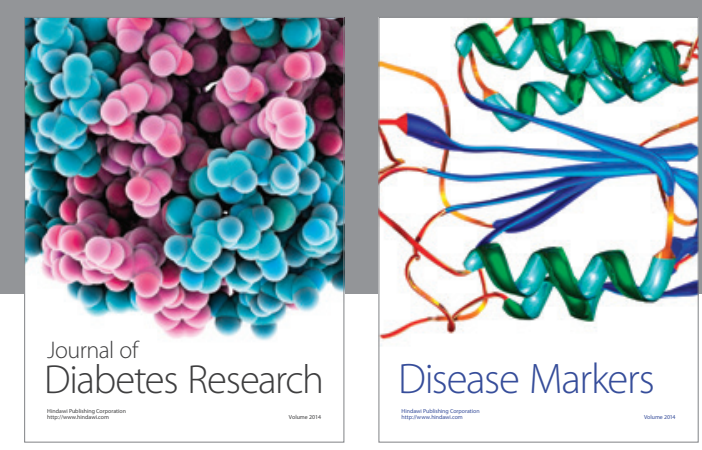

Disease Markers
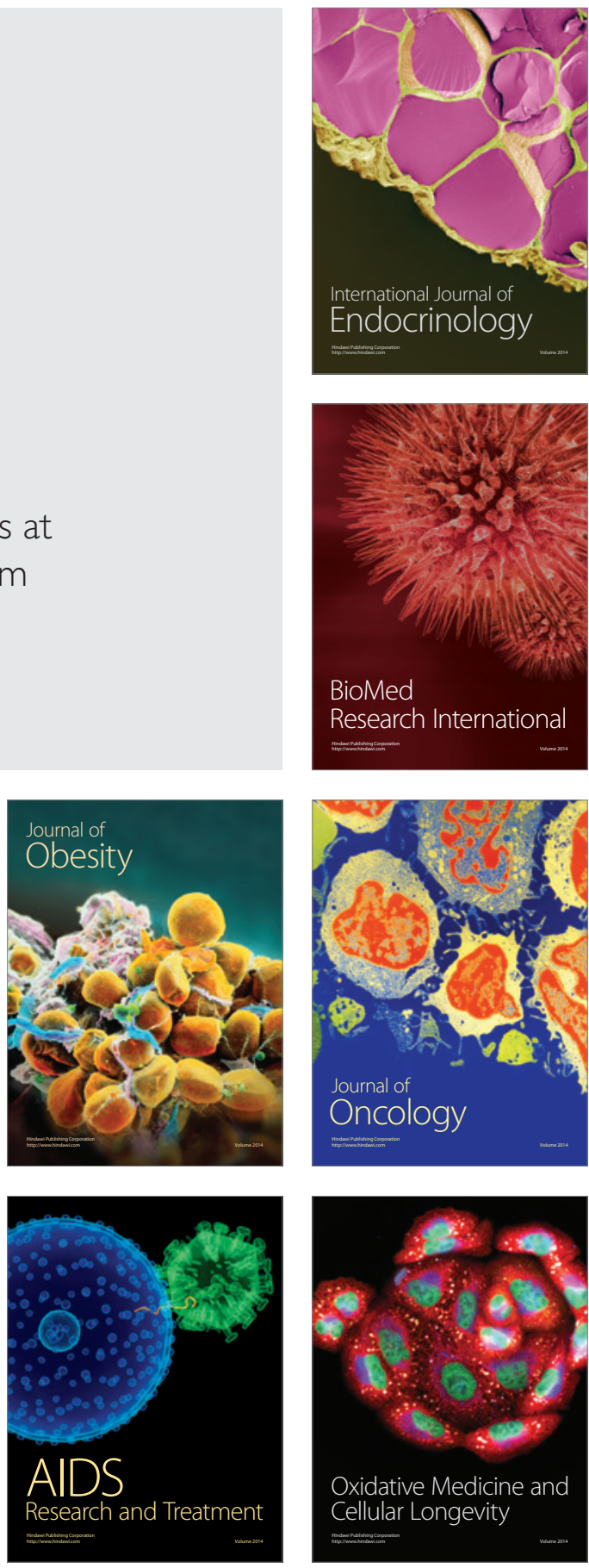